\title{
Multiple linear and principal component regressions for modelling ecotoxicity bioassay response
}

\author{
Ana I. Gomes, José C.M. Pires, Sónia A. Figueiredo, and Rui A.R. Boaventura
}

\begin{abstract}
The ecotoxicological response of the living organisms in an aquatic system depends on the physical, chemical and bacteriological variables, as well as the interactions between them. An important challenge to scientists is to understand the interaction and behaviour of factors involved in a multidimensional process such as the ecotoxicological response. With this aim, multiple linear regression (MLR) and principal component regression were applied to the ecotoxicity bioassay response of Chlorella vulgaris and Vibrio fischeri in water collected at seven sites of Leça river during five monitoring campaigns (February, May, June, August and September of 2006). The river water characterization included the analysis of 22 physicochemical and 3 microbiological parameters. The model that best fitted the data was MLR, which shows: (i) a negative correlation with dissolved organic carbon, zinc and manganese, and a positive one with turbidity and arsenic, regarding C. vulgaris toxic response; (ii) a negative correlation with conductivity and turbidity and a positive one with phosphorus, hardness, iron, mercury, arsenic and faecal coliforms, concerning $V$. fischeri toxic response. This integrated assessment may allow the evaluation of the eff ect of future pollution abatement measures over the water quality of Leça River.
\end{abstract}

Keywords: Chlorella vulgaris; ecotoxicological assessment; multiple linear regression; principal component regression; surface water quality; Vibriofischeri

\section{Introduction}

Pollution of surface water with toxic chemicals and excess of nutrients, resulting from storm water runoff, mains leakage leaching, and ground water discharges, has been an issue of worldwide environmental concern.[1] The water quality assessment must comprise an ecotoxicological characterization, which allows properly evaluating the potential risks of effluent discharges, especially when they are complex.[2] The ecotoxicity evaluation by means of acute bioassays may bring quick and valuable information.[3,4] However, most of the ecotoxicity test methods were established to measure the toxicity of pure single chemicals and not to be applied to unknown environmental water samples with complex components. Since chemicals are present in environmental water as a complex mixture, their potential ecotoxicological eff ects are much complicated due to their interactions. [5-9] In addition, even if the toxicity of an environmental sample is tested, there is no guidance on how to evaluate the water quality in terms of protection of aquatic living organisms.[6] It is difficult to extrapolate the potential damage on the aquatic ecosystem from the test results with specific species, particularly because not all species respond identically to the same pollution stresses.[10] It is also quite difficult to evaluate the actual exposure levels and ecotoxicological eff ects of all coexisting chemicals on aquatic organisms by measuring the concentrations of individual chemicals (United States Environmental Protection Agency - USEPA).[11,12] It must also be kept in mind that there is an uncertainty factor when laboratory results are extrapolated to field conditions because of the simultaneous influence of a number of environmental and biological factors (bioavailability, toxicokinetics, sensitivity of organisms, etc.).[4] However, direct toxicity test of environmental water sample can provide an integral view on ecotoxicological eff ects of all chemicals coexisting in water as a mixture and has been widely used in safety assessment of water quality.[6,13,14]

The study of ecological properties of diff erent organization levels may reveal changes of potential ecological signification that cannot be detected by other analyses.[1] The bacterium Vibrio fischeri (decomposer) and the alga Chlorella vulgaris (first producer) were selected for this study because they belong to diff erent trophic levels and are widely used in ecotoxicity tests.[1,2] One of the advantages of these tests is the fast assessment of ecotoxicity.

The ecotoxicological response of the living organisms in an aquatic system depends on several variables, such as nutrient quantitative and qualitative profiles, temperature, 
physicochemical properties of the water and grazing pressure.[15] An important challenge for scientists is to develop analytical tools that could be used to understand the interaction and behaviour of factors involved in a multidimensional process [16] such as the ecotoxicological response, and to provide the necessary tools for monitoring and management of resources. Modelling is regarded as an important analytical tool for biological and ecological studies.[17,18]

Multivariate statistical techniques are useful for the evaluation and interpretation of large and complex water quality data sets.[19] Multiple linear regression (MLR) is one of the most widely used methodologies for expressing the dependence of a response variable on several explanatory (predictor) variables.[16,20-22] Principal component analysis (PCA) is useful in pre-processing methodology for mitigating the problem of multicollinearity (when the explanatory variables are correlated with each other) and for exploring the relations among the input variables, particularly if it is not obvious which of the variables should be the predictors. PCA creates new variables, the principal components (PCs), by linear combination of the original variables. PCs are uncorrelated to each other, removing the multicollinearity problem. They are interpreted by the association with original variables through the corresponding factor loadings. Principal component regression (PCR) is the linear model that relates the dependent variable with these PCs. Both MLR [20,23] and PCR [16] approaches have been applied in studies of waterquality.

The utility of $C$. vulgaris as test organism is based on its short life cycle, making it easy to study the exposure of several generations.[24] It is easily cultured in laboratory and is widespread in nature, being found in freshwater, saltwater and soil.[25]

Vibrio fischeri is a Gram-negative bioluminescent marine bacterium that forms mutually symbiotic relationships with various species of fish and squids or can be found living freely in the oceans.[26] The main advantages of using this species in ecotoxicity is the short time required to obtain results, the simplicity of the test and high reproducibility of results.[27]

The present study aims to model $C$. vulgaris and $V$. fischeri bioassays toxic response in concern to the Leça river water characterization by MLR and PCR. The achieved models lead to infer possible influences of physicochemical and microbiological variables of river water in bioassay results.

\section{Materials and methods}

\subsection{Area description - sampling sites}

The Leça river flows through a highly populated and industrialized area in the north of Portugal and receives a complex mixture of pollutants from poorly treated or untreated domestic, agricultural and industrial effluents, and other contaminated waters both from point and diff use sources.

Figure 1 presents the location of Leça river in the north of Portugal. It rises in the Mountain of Santa Luzia at Santo Tirso and flows for approximately $48 \mathrm{~km}$ until the Atlantic Ocean. Water samples were collected at seven sampling sites along the river: site 1 is located in the upstream part of the river in a main rural area; both sites 2 and 4 are located downstream from wastewater treatment plants in a highly populated area; sites 3 and 5 are situated in a strongly populated and industrialized area; site 6 is in a revitalized area with a recreational park; and site 7 is some metres upstream from the river mouth, before a waterfall, and therefore it does not receive any marine influence. Water samples were collected in five diff erent periods - February, May, June, August and September of 2006, one day in each month (not always the same). Most of the samples were collected from bridges, in order to obtain samples from running water,

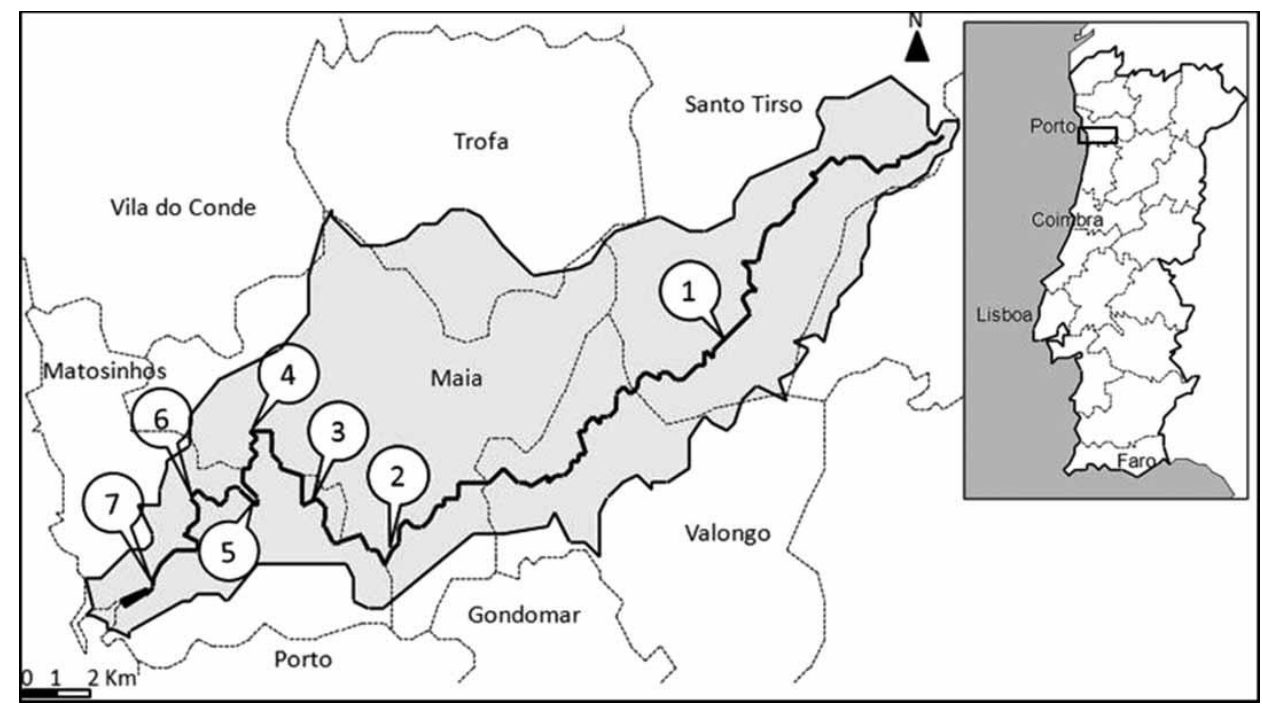

Figure 1. Leça river basin showing the geographical location of the sampling sites. 
Table 1. Analytical procedures.

\begin{tabular}{|c|c|c|}
\hline Parameter & Method & Equipment \\
\hline \multicolumn{3}{|c|}{ Physicochemical parameters } \\
\hline Temperature & Thermometry & $\begin{array}{l}\text { Multiparameter analyser HANNA } \\
\text { Instruments model } 991003\end{array}$ \\
\hline $\mathrm{pH}$ & Electrometry & \\
\hline ORP & Electrometry & \\
\hline Dissolved oxygen (DO) & Membrane electrode & $\begin{array}{l}\text { DO meter HANNA Instruments model } \\
9143\end{array}$ \\
\hline Conductivity & Conductimetry & Conductivity meter WTW model LF 330 \\
\hline Turbidity & Nephelometry Method 2130 B [28] & Turbiquant 3000 IR, Merck \\
\hline Colour & $\begin{array}{l}\text { Spectrophotometry (platinum-cobalt) Method } \\
110.2[29]\end{array}$ & $\begin{array}{l}\text { UV/Vis Spectrometer PYE Unicam PU } \\
8600\end{array}$ \\
\hline Dissolved organic carbon (DOC) & High-temperature combustion Method 5310 B [28] & Shimadzu analyser 5000 A - \\
\hline $\begin{array}{l}\text { Biochemical oxygen demand } \\
\text { (BOD) }\end{array}$ & 5-Day BOD Test Method 5210 B [28] & DO meter Crison OXI 45 \\
\hline Total nitrogen & Persulfate digestion method 4500N C [28] & $\begin{array}{l}\text { UV/Vis Spectrometer PYE Unicam PU } \\
8600\end{array}$ \\
\hline Total phosphorus & $\begin{array}{l}\text { Persulfate digestion+ascorbic acid method } 4500 \mathrm{PE} \\
\text { [28] }\end{array}$ & $\begin{array}{l}\text { UV/Vis Spectrometer PYE Unicam PU } \\
8600\end{array}$ \\
\hline Hardness & EDTA titrimetry method $2340 \mathrm{C}[28]$ & \\
\hline $\begin{array}{l}\text { Dissolved } \mathrm{Cd}, \mathrm{Cr}, \mathrm{Cu}, \mathrm{Fe}, \mathrm{Mn} \text {, } \\
\quad \mathrm{Ni}, \mathrm{Pb} \text { and } \mathrm{Zn}\end{array}$ & $\begin{array}{l}\text { Atomic absorption spectrometry - flame methods } \\
3111 \mathrm{~B} \text { and D [28] }\end{array}$ & AAS GBC 932 plus \\
\hline Dissolved As and $\mathrm{Hg}$ & $\begin{array}{l}\text { Hydride generation/cold-vapour atomic absorption } \\
\text { spectrometry Methods } 3112 \text { B and } 3114 \text { C [28] }\end{array}$ & AAS GBC 932 plus and GBC HG 3000 \\
\hline \multicolumn{3}{|c|}{ Bacteriological parameters } \\
\hline Total coliforms & Membrane filtration ISO Standard [30] & \\
\hline Faecal coliforms & Membrane filtration ISO Standard [30] & \\
\hline Faecal streptococcus & $\begin{array}{l}\text { Membrane filtration ISO Standard [31] } \\
\text { Ecotoxicological parameters }\end{array}$ & \\
\hline Microtox ${ }^{\circledR}$ inhibition & $\begin{array}{l}\text { Bioluminescent inhibition test of bacteria Vibrio } \\
\text { fischeri (15 min) ISO Standard [32] }\end{array}$ & $\begin{array}{l}\text { Microtox Analyser 2055, Microbics } \\
\text { Corporation (at present time, AZUR) } \\
\text { Environmental }\end{array}$ \\
\hline Green algae inhibition & $\begin{array}{l}\text { Inhibition growth test of microalgae Chlorella } \\
\text { vulgaris USEPA Guideline [14] }\end{array}$ & Shimadzu UV/Vis spectrometer \\
\hline
\end{tabular}

which were representative of the river water. Grab samples were manually collected by immersing the plastic bottles into the river.

\subsection{Analysis of the water samples}

The analytical procedures used to characterize the water samples are presented in Table 1. All used reagents were of analytical grade.

Temperature, $\mathrm{pH}$ and oxidation--reduction potential, dissolved oxygen and conductivity were measured in situ. Water samples were stored at $4{ }^{\circ} \mathrm{C}$ (no chemical preservatives were added) and analysed in duplicate within $24 \mathrm{~h}$. For dissolved organic carbon (DOC) and metals, a filtration by $0.45-\mu \mathrm{m}$ pore diameter membrane filter was performed. Bioassays were performed within (the maximum) $48 \mathrm{~h}$ after sampling.

The bioluminescent inhibition toxicity tests (ISO 11348) were performed using the bacteria $V$. fischeri (NRRL B 11177). Tested concentrations were 5.6\%, 11.3\%, 22.5\% and $45 \%(\mathrm{v} / \mathrm{v})$. The values of $\mathrm{EC}_{50}$ (eff ective concentration of the sample that causes 50 inhibition to the test organisms) and the corresponding 95\% confidence intervals were determined for 5 and 15 min of bacterial exposure.

The green algae inhibition growth tests were performed with the microalgae $C$. vulgaris according to USEPA Guideline [14]. Three replicates of each sample were tested for five diff erent concentrations $(10 \%, 20 \%, 40 \%, 60 \%$ and $80 \%$ ). The test solutions were incubated for $72 \mathrm{~h}$, under continuous cool white fluorescent light. Agitation was performed manually twice per day. Initial and final absorbance was measured at $440 \mathrm{~nm}$ [33] to evaluate the growth of the algal population. A calibration curve was used to convert the absorbance in cell concentration (cells $/ \mathrm{mL}$ ) using the experimental linear relation obtained: (cell density) $=$ $6.42 \times 104+8.00 \times 107 \times($ absorbance at $440 \mathrm{~nm})$, with a square correlation factor of 0.995 .

The acceptability criterion considered was variability $<20 \%$ among replicates. Shapiro-Wilk's normality test and Bartlett's test for homogeneity of variance were performed to validate data, and Dunnett's procedure was followed [14]. Since these assumptions were met, $\mathrm{EC}_{50}$ was calculated by linear interpolation. 
The reference toxicants used to validate tests were phenol and potassium dichromate, respectively, for $V$. fisheri and $C$. vulgaris bioassays.

The toxic response was evaluated through the calculation iff EC 5 5 o eff ective concentration that causes $50 \%$ pose, $\mathrm{EC}_{50}$ was converted in toxicity units, $\mathrm{TU}_{50}\left(\mathrm{TU}_{50}=\right.$ $100 / \mathrm{EC}_{50}$ ), as suggested by Wisconsin Department of Natural Resources.[34] Because EC $_{50}$ was expressed in percentage, the sample is considered 'not toxic' when $\mathrm{TU}_{50}=1$

and biostimulated when $\mathrm{TU}_{50}<1$.

\subsection{Regression models}

The data considered for this analysis were the mean of replicates. Before the determination of the models, the data were $Z$ standardized to have zero mean and unit standard deviation. MLR attempts to model the relationship between two or more explanatory variables and a response variable, by fitting a linear equation to the observed data.[35,36] The dependent variable $(y)$ is given by

$$
y=\hat{\beta}_{0}+\sum_{i=1}^{k} \hat{\beta}_{i} x_{i}+\varepsilon
$$

where $x_{i}(i=1, \ldots, k)$ are the explanatory variables, $\hat{\beta_{i}}(i=$ $0, \ldots, k)$ are the regression coefficients, and $\varepsilon$ is the error associated with the regression and assumed to be normally distributed with both expectation value zero and constant variance.[37]

The predicted value given by the regression model $\left(y^{\wedge}\right)$ is calculated by

$$
\hat{y}=\hat{\beta}_{0}+\sum_{i=1}^{k} \hat{\beta}_{i} x_{i}
$$

To estimate the regression coefficients $\hat{\beta_{i}}$ the minimization of the sum of squared errors (SSE) method is used, as follows:

$$
\hat{\beta} i=\arg \min \sum_{i=0}^{k}\left(y_{i}-\hat{y}_{i}\right)^{2}
$$

PCR is a method that combines linear regression and PCA.[36] Essentially, PCA maximizes the correlation between the original variables to form new variables, the PCs that are orthogonal and uncorrelated. These variables are linear combinations of the original variables. The PCs are ordered in such a way that the first component has the largest fraction of the original data variability.[16,38] To evaluate the influence of each variable in the PCs, varimax rotation is generally used to obtain the rotated factor loadings that represent the contribution of each variable in a specific PC. PCR establishes a relationship between the output variable $(y)$ and the selected PC obtained from the explanatory variables $\left(x_{i}\right)$.[36]
The significance of the regression coefficients in the MLR and PCR models was evaluated through the calculation of their confidence intervals.[36,39] The regression coefficient $\hat{\beta_{i}}$ is statistically significant if:

$$
\hat{\beta}_{i}=\arg \min \sum_{i=0}^{k}\left(y_{i}-\hat{y}_{i}\right)^{2}
$$

where $t$ is the Student $t$ distribution, $n$ is the number of points, $k$ is the number of parameters, $\alpha$ is the signif1 ance level, $\hat{\sigma}$ is the standard deviation given by and $\mathrm{SSE} /(n-k-f) \mathrm{Sxx}_{i}$ is the sum of the squares related to $x_{i}$ given by ${ }_{j=1}\left(x_{i j}-\bar{x}_{i}\right)^{2}$.

Hence, several MLR and PCR models were determined by testing all combinations of the explanatory variables, selecting the ones that presented the lowest SSE and all statistically significant regression coefficients.[36]

The PCs were calculated using Matlab, whereas MLR and PCR models were evaluated by developed subroutines in Microsoft Visual Basic for Applications (Microsoft Excel).

\subsection{Performance indexes}

The performances of MLR and PCR models in the prediction of $C$. vulgaris and $V$. fischeri toxic response were evaluated through calculation of the coefficient of determination $\left(R^{2}\right)$, mean absolute error (MAE), root mean squared error (RMSE) and index of agreement $\left(d_{2}\right)$.[40,41] The MAE and the RMSE measures residual errors, which gives a global idea of the diff erence between the observed and modelled values. The values $d_{2}$ indicate the degree to which the predictions are error free, because it compares the difference between the mean, the predicted and the observed concentrations.

\section{Results}

The physicochemical, bacteriological and ecotoxicological results, presented in a previous study, [42] are shown in Table 2 for physicochemical data and in Figures 2 and 3 for ecotoxicological data. For bacteriological parameters, the maximum concentrations of total coliforms, faecal coliforms and faecal streptococcus were, respectively, $5.5 \times 10^{7}, 5.0 \times 10^{6}$ and $3.0 \times 10^{5} \mathrm{CFU} / 100 \mathrm{~mL}$, all obtained at site 2 . From the dissolved metals evaluated ( $\mathrm{As}, \mathrm{Cd}, \mathrm{Cr}, \mathrm{Cu}, \mathrm{Fe}, \mathrm{Hg}, \mathrm{Mn}, \mathrm{Ni}, \mathrm{Pb}$ and $\mathrm{Zn}$ ) only zinc $(0.08-0.22 \mathrm{mg} / \mathrm{L})$, manganese $(<0.13 \mathrm{mg} / \mathrm{L})$, mercury $(0.5-6.5 \mu \mathrm{g} / \mathrm{L})$, arsenic $(0.5-3.0 \mu \mathrm{g} / \mathrm{L})$ and iron $(0.20-0.40 \mathrm{mg} / \mathrm{L})$ were detected.

The models were determined to model $C$. vulgaris and $V$. fischeri toxic response using physicochemical and bacteriological variables as predictors. Regarding V. fischeri results, only the 15 min-toxic responses were used in the regression models. From the 25 monitored variables, only 15 were applied for models development. Variables 
Table 2. Physicochemical characterization of Leça river water samples.

Physicochemical parameters

\begin{tabular}{|c|c|c|c|c|c|c|c|c|c|c|c|c|c|}
\hline $\begin{array}{l}\text { Sampling } \\
\text { sites }\end{array}$ & Month & $\begin{array}{l}\text { Temp. } \\
\left({ }^{\circ} \mathrm{C}\right)\end{array}$ & $\mathrm{pH}$ & $\begin{array}{l}\text { ORP } \\
(\mathrm{mV})\end{array}$ & $\begin{array}{l}\text { Cond. } \\
(\mu \mathrm{S} / \mathrm{cm})\end{array}$ & $\begin{array}{c}\mathrm{DO} \\
(\mathrm{mg} / \mathrm{L})\end{array}$ & $\begin{array}{c}\text { DOC } \\
(\mathrm{mg} / \mathrm{L})\end{array}$ & $\begin{array}{c}\mathrm{BOD} \\
\left(\mathrm{mg} \mathrm{O}_{2} / \mathrm{L}\right)\end{array}$ & $\begin{array}{l}\text { Turb. } \\
\text { (NTU) }\end{array}$ & $\begin{array}{l}\text { Colour } \\
\text { (Pt-Co) }\end{array}$ & $\begin{array}{c}\text { Total N } \\
(\mathrm{mg} \mathrm{N} / \mathrm{L})\end{array}$ & $\begin{array}{c}\text { Total P } \\
(\mathrm{mg} \mathrm{P} / \mathrm{L})\end{array}$ & $\begin{array}{c}\text { Hardness } \\
\left(\mathrm{mg} \mathrm{CaCO}_{3} / \mathrm{L}\right)\end{array}$ \\
\hline \multirow[t]{5}{*}{1} & February & 9.8 & 7.14 & 235 & 121 & 10.5 & 3.6 & - & 28 & 10 & 27.4 & 0.8 & 37.1 \\
\hline & May & 12.1 & 6.75 & 263 & 73 & 8.5 & 1.3 & 2.6 & 0.60 & 0 & 2.3 & $<0.1$ & 28.7 \\
\hline & June & 17.0 & 6.11 & 176 & 89 & 8.3 & 2.2 & 0.6 & 0.06 & 14 & 7.9 & 0.1 & 40.7 \\
\hline & August & 21.0 & 6.61 & 79 & 179 & 6.1 & 3.8 & 1.5 & 3.5 & 1 & 5.4 & 0.2 & 44.3 \\
\hline & September & 18.0 & 5.88 & 153 & 123 & 6.8 & 11.3 & 5.6 & 240 & 43 & 3.3 & 0.2 & 35.9 \\
\hline \multirow[t]{5}{*}{2} & February & 9.8 & 7.07 & 187 & 150 & 10.3 & 5.7 & - & 110 & 21 & 35.5 & 0.8 & 46.7 \\
\hline & May & 14.4 & 6.04 & 244 & 226 & 8.2 & 3.0 & 5.1 & 3.5 & 2 & 11.7 & 0.8 & 67.0 \\
\hline & June & 20.0 & 5.64 & 222 & 483 & 7.9 & 12.0 & 10.2 & 7.8 & 43 & 30.7 & 2.4 & 89.7 \\
\hline & August & 22.2 & 6.00 & 71 & 1050 & 5.4 & 24.6 & 21.2 & 12 & 44 & 70.7 & 3.7 & 140.0 \\
\hline & September & 18.7 & 5.85 & 133 & 160 & 5.0 & 11.1 & 9.6 & 130 & 32 & 4.7 & 1.8 & 75.2 \\
\hline \multirow[t]{5}{*}{3} & February & 10.6 & 6.94 & 161 & 179 & 9.5 & 5.4 & - & 60 & 13 & 28.3 & 0.9 & 51.4 \\
\hline & May & 15.0 & 6.03 & 236 & 251 & 7.8 & 4.3 & 6.0 & 3.5 & 1 & 17.4 & 0.9 & 71.8 \\
\hline & June & 20.2 & 5.96 & 197 & 496 & 7.5 & 13.6 & 15.0 & 9.3 & 46 & 38.2 & 2.8 & 101.7 \\
\hline & August & 22.5 & 5.96 & 109 & 857 & 5.2 & 23.1 & 10.6 & 8.5 & 35 & 57.8 & 4.3 & 140.0 \\
\hline & September & 18.6 & 6.55 & 80 & 174 & 5.3 & 11.0 & 12.0 & 170 & 33 & 3.5 & 2.3 & 83.6 \\
\hline \multirow[t]{5}{*}{4} & February & 10.9 & 7.01 & 187 & 180 & 9.8 & 4.7 & - & 65 & 16 & 30.9 & 0.6 & 89.7 \\
\hline & May & 15.4 & 6.28 & 204 & 287 & 7.8 & 4.8 & 7.7 & 4.3 & 3 & 22.2 & 1.0 & 82.5 \\
\hline & June & 20.5 & 6.12 & 206 & 577 & 8.1 & 16.6 & 15.7 & 17 & 62 & 33.7 & 3.0 & 99.3 \\
\hline & August & 23.0 & 6.07 & 94 & 935 & 5.8 & 21.7 & 31.3 & 10 & 38 & 54.7 & 2.7 & 130.4 \\
\hline & September & 18.6 & 5.91 & 105 & 178 & 5.2 & 10.5 & 15.6 & 260 & 28 & 12.8 & 2.8 & 90.5 \\
\hline \multirow[t]{5}{*}{5} & February & 10.4 & 6.65 & 183 & 176 & 9.8 & 4.4 & - & 65 & 15 & 26.4 & 0.8 & 69.4 \\
\hline & May & 15.0 & 6.07 & 230 & 265 & 8.0 & 3.8 & 12.0 & 6.7 & 1 & 14.4 & 0.9 & 76.6 \\
\hline & June & 20.4 & 6.05 & 203 & 556 & 7.9 & 15.3 & 12.6 & 12 & 57 & 30.7 & 2.6 & 100.5 \\
\hline & August & 23.3 & 5.97 & 72 & 952 & 5.5 & 21.8 & 20.2 & 13 & 32 & 57.0 & 3.0 & 140.0 \\
\hline & September & 18.7 & 6.07 & 98 & 194 & 4.5 & 10.9 & 13.2 & 180 & 30 & 5.4 & 1.8 & 82.5 \\
\hline \multirow[t]{5}{*}{6} & February & 10.7 & 6.50 & 158 & 192 & 11.7 & 4.8 & - & 100 & 16 & 25.0 & 0.7 & 62.2 \\
\hline & May & 16.0 & 6.34 & 197 & 318 & 7.7 & 5.6 & 8.7 & 10 & 3 & 19.8 & 1.2 & 82.5 \\
\hline & June & 21.8 & 6.07 & 241 & 560 & 7.9 & 15.5 & 18.9 & 11 & 61 & 30.4 & 2.7 & 102.9 \\
\hline & August & 22.4 & 6.23 & 109 & 932 & 5.3 & 20.7 & 22.7 & 13 & 39 & 56.4 & 8.2 & 131.6 \\
\hline & September & 18.3 & 6.41 & 149 & 305 & 6.3 & 12.7 & 3.8 & 200 & 29 & 11.1 & 2.5 & 89.7 \\
\hline \multirow[t]{5}{*}{7} & February & 10.9 & 6.98 & 145 & 187 & 10.3 & 5.0 & - & 120 & 18 & 27.7 & 0.7 & 58.6 \\
\hline & May & 16.0 & 6.25 & 204 & 343 & 8.3 & 5.7 & 9.3 & 8.1 & 3 & 27.9 & 1.1 & 88.5 \\
\hline & June & 22.9 & 6.05 & 253 & 578 & 7.6 & 14.8 & 19.2 & 12 & 58 & 34.0 & 2.8 & 117.2 \\
\hline & August & 23.2 & 5.98 & 113 & 1769 & 5.2 & 19.1 & 24.7 & 8.2 & 38 & 26.0 & 12.2 & 226.0 \\
\hline & September & 18.2 & 6.74 & 90 & 298 & 5.6 & 12.7 & 13.6 & 180 & 28 & 117.0 & 2.8 & 100.4 \\
\hline
\end{tabular}




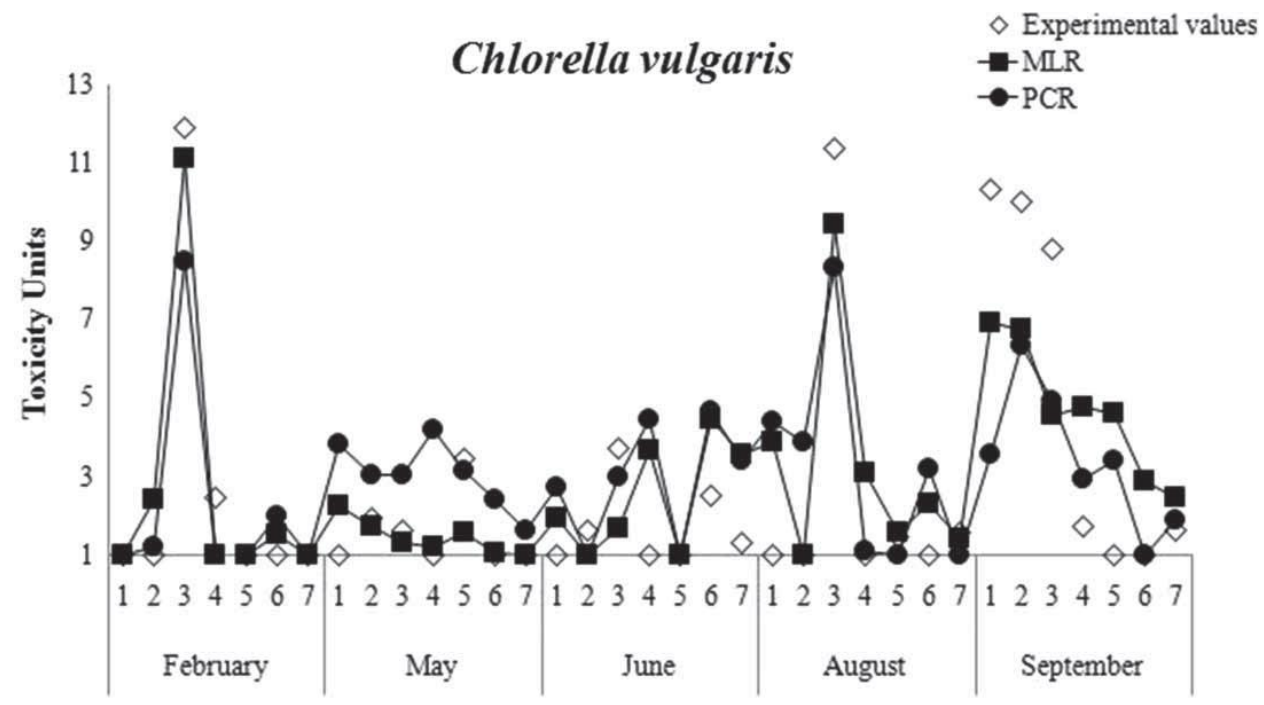

Figure 2. Comparison between experimental values and values given by MLR and PCR models for Chlorella vulgaris toxic response.

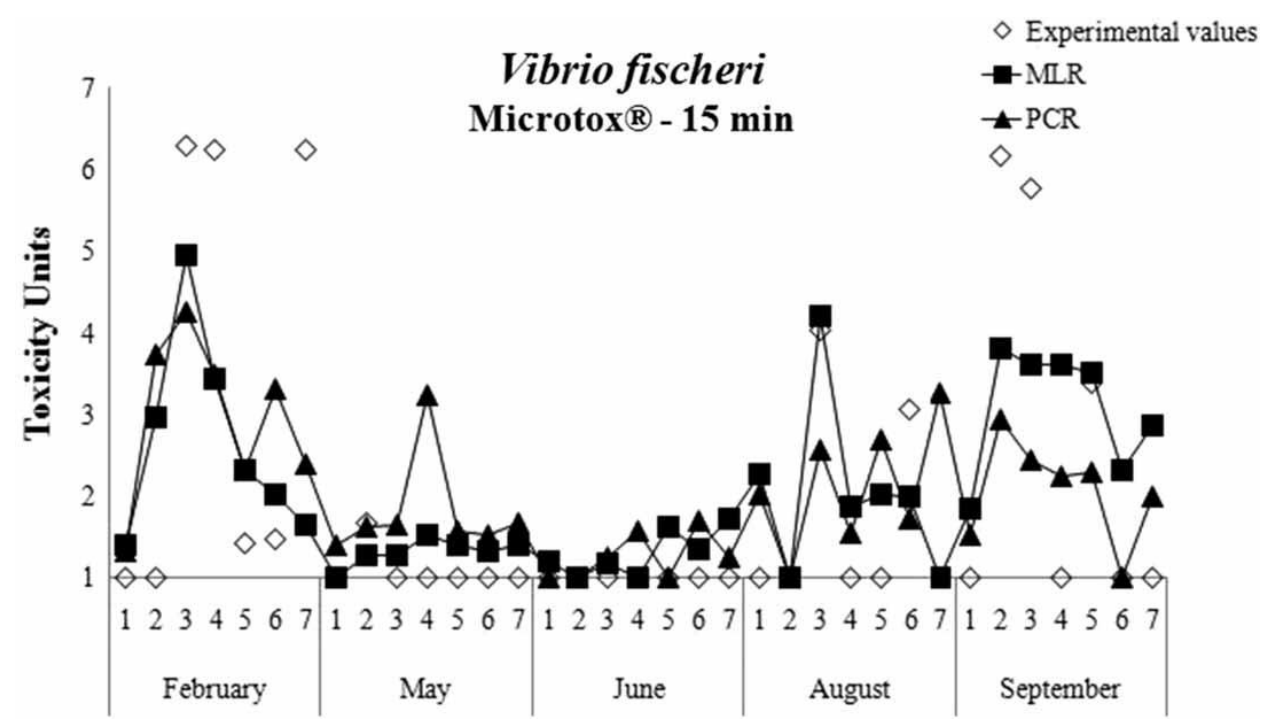

Figure 3. Comparison between experimental values and values given by MLR and PCR models for Vibrio fischeri toxic response.

that were measured in situ and that presented always values below the detection limit were not considered. Both MLR and PCR models were determined by statistically significant regression coefficients with a significance level of 0.05 .

The MLR led to the following results: (i) C. vulgaris toxic response was negatively aff ected by DOC, $\mathrm{Zn}$ and $\mathrm{Mn}$, and positively aff ected by turbidity and As; and (ii) $\mathrm{V}$. fischeri toxic response was negatively aff ected by conductivity and turbidity, and positively aff ected by phosphorus, hardness, $\mathrm{Fe}, \mathrm{Hg}$, As and faecal coliforms. The regression models obtained by MLR were as follows:

$$
\begin{aligned}
\text { C.vulgaris }= & 2.719-2.193(\mathrm{DOC})-1.399(\mathrm{Zn}) \\
& -0.782(\mathrm{Mn})+1.651 \text { (turbidity) } \\
& +3.643(\mathrm{As})
\end{aligned}
$$

$$
\begin{aligned}
V . f i s c h e r i= & 1.849-5.845 \text { (conductivity) } \\
& -0.860 \text { (turbidity) } \\
& +0.971 \text { (phosphorus) }+2.951 \text { (hardness) } \\
& +0.551(\mathrm{Fe})+1.624(\mathrm{Hg}) \\
& +0.595(\mathrm{As})+0.657 \text { (faecal coliforms) }
\end{aligned}
$$

PCA was performed to obtain in the PCs all variance contained in the original data. Thus, 15 PCs were determined. Table 3 presents the results from PCA showing the rotated factor loadings for all 15 PCs. Values in bold correspond to the greatest contributions of the original variables on the PCs. PC1 had important contributions from conductivity, DOC, total nitrogen, total phosphorus, hardness and Hg. PC3 was heavily loaded by all bacteriological 
Table 3. Rotated factor loadings for all principal components (PC) of the physical, chemical and bacteriological variables.

\begin{tabular}{|c|c|c|c|c|c|c|c|c|c|c|c|c|c|c|c|}
\hline Variables & $\mathrm{PC} 1$ & PC2 & PC3 & $\mathrm{PC} 4$ & PC5 & PC6 & PC7 & PC8 & PC9 & PC10 & PC11 & PC12 & PC13 & PC14 & PC15 \\
\hline Conduct & 0.896 & & & -0.130 & 0.213 & & -0.088 & & & & & & & -0.007 & 0.085 \\
\hline DOC & & 0.052 & 0.415 & & & 0.299 & & & & & & 0.030 & & & \\
\hline Turbic & 0.169 & & & & & & & & 0.009 & & & & 0.001 & & \\
\hline Colour & -0.352 & & & -0.109 & & & 0.332 & & -0.002 & 0.040 & & & & & 0.001 \\
\hline Total & 0.884 & 0.005 & 0.235 & 0.188 & 0.254 & & -0.090 & & -0. & & 0.097 & & & 0.159 & -0.007 \\
\hline Total & -0.938 & 0.007 & 0.028 & -0.126 & -0.043 & & -0.0 & -0.143 & -0. & 0.0 & -0.257 & & -0 & & -0.003 \\
\hline Hardi & -0.940 & 0.013 & 0.178 & -0.177 & 0.058 & 0.0 & 0.0 & -0.110 & & & & & & -0 & -0.061 \\
\hline $\mathrm{Zn}$ & 0.131 & -0.037 & -0.056 & 0.980 & -0.059 & & & 0.084 & & -0. & & -0.003 & & & 0.000 \\
\hline & 0.146 & 0.184 & -0.111 & 0.064 & -0.186 & & & -0.204 & 0.008 & & 0.001 & -0.004 & 0.002 & -0.002 & -0.001 \\
\hline $\operatorname{Mn}($ & -0.009 & 0.978 & -0.025 & -0.037 & 0.064 & & 0.153 & -0.089 & -0.001 & 0.014 & 0.000 & -0.002 & & & 0.000 \\
\hline $\mathrm{Hg}(\mu \mathrm{g} / \mathrm{L})$ & -0.725 & -0.083 & 0.181 & 0.051 & -0.070 & & -0.259 & 0.062 & 0.006 & -0.502 & 0.004 & & & & 0.002 \\
\hline As $(\mu \mathrm{g} / \mathrm{L})$ & -0.296 & 0.120 & 0.206 & 0.094 & 0.120 & 0.877 & 0.119 & -0.213 & & -0.0 & -0.003 & & 0.002 & 0.002 & 0.001 \\
\hline Total coliforms (CFU/100mL) & -0.207 & -0.046 & 0.884 & -0.055 & 0.007 & 0.266 & -0.094 & & 0.102 & -0.067 & 0.046 & 0.268 & 0.014 & -0.009 & 0.001 \\
\hline Faecal coliforms (CFU/100mL) & -0.190 & 0.009 & 0.905 & -0.065 & 0.144 & 0.007 & -0.127 & & -0.305 & 0.019 & -0.001 & -0.068 & 0.006 & 0.007 & 0.002 \\
\hline Faecal streptococcus (CFU/100mL) & -0.161 & -0.006 & 0.960 & 0.016 & -0.083 & 0.044 & 0.047 & -0.080 & 0.138 & -0.021 & -0.024 & -0.120 & -0.008 & 0.005 & -0.001 \\
\hline
\end{tabular}

Note: Values in bold correspond to the greatest contributions of the original variables on the PCs.

Table 4. Transformation matrix used to calculate the PCs from the physical, chemical and bacteriological variables.

\begin{tabular}{|c|c|c|c|c|c|c|c|c|c|c|c|c|c|c|c|}
\hline Variables & PC1 & $\mathrm{PC} 2$ & PC3 & PC4 & PC5 & PC6 & PC7 & PC8 & PC9 & PC10 & PC11 & PC12 & PC13 & PC14 & PC15 \\
\hline Conductivity & 0.367 & 0.020 & -0.212 & 0.048 & -0.011 & 0.072 & -0.087 & 0.0 & -0.138 & 0.041 & -0.130 & 0.015 & -0.113 & -0.215 & -0.841 \\
\hline DOC & 0.354 & -0.177 & & & & -0.164 & & & -0231 & & -0.117 & & 0.601 & & -0.040 \\
\hline idity & -0.103 & -0.233 & & -0.274 & & & 0.379 & & 0.101 & -0.100 & & 0.180 & -0.187 & 0.020 & 0.105 \\
\hline Colour & & -0.484 & 0.075 & 0.060 & 0.094 & -0.159 & -0.249 & 0.548 & -0.132 & & 0.225 & -0.074 & -0 & -0.323 & \\
\hline Total nitrogen & & 0.094 & -0.205 & -0.192 & -0.128 & & -0.211 & -0.010 & -0 . & 0.073 & -0.103 & 0.432 & & & 0.224 \\
\hline Total & 18 & -0.067 & -0.3 & -0.0 & 0.2 & & -0.0 & - & 0.579 & -0.184 & 0.346 & -0.429 & & 0.2 & 0.002 \\
\hline Hardn & 0.344 & -0.039 & -0.2 & 0.061 & 0.143 & 0.199 & -0.136 & -0.258 & -0.117 & -0.370 & -0.306 & 0.104 & & -0.4 & 0.358 \\
\hline $\mathrm{Zn}$ & -0.098 & 0.018 & 0.06 & -0.785 & -0.273 & & -0.199 & 0.249 & -0.05 & -0.118 & -0.021 & -0.202 & & -0 & -0.065 \\
\hline $\mathrm{Fe}$ & -0.067 & -0.592 & 0.14 & -0.0 & 0.007 & 0.043 & -0.3 & -0.59 & -0 & 0.319 & -0 & -0 . & & & -0.045 \\
\hline $\mathrm{Mn}$ & 0.029 & -0.384 & 0.012 & 0.246 & -0.504 & 0.518 & & 0.072 & -0.046 & -0.040 & 0.009 & -0.018 & 0.003 & 0.005 & 0.016 \\
\hline $\mathrm{Hg}$ & 0.299 & 0.153 & -0.163 & -0.303 & 0.090 & -0.082 & 0.457 & -0.147 & -0.204 & 0.577 & 0.188 & -0.141 & 0.001 & -0.2 & 0.193 \\
\hline As & 0.240 & -0.226 & 0.077 & -0.266 & -0.343 & -0.576 & 0.240 & -0.122 & 0.401 & -0.194 & & 0.255 & & -0.0 & -0.031 \\
\hline Tota & 0.265 & 0.169 & 0.446 & -0.008 & -0.039 & -0.103 & 0.119 & -0.206 & -0.38 & -0.403 & & -0.460 & & & 0.029 \\
\hline & 0.244 & 0.225 & 0.424 & 0.156 & -0.095 & & -0.152 & 0.153 & & 0.389 & & & & -0.115 & 0.097 \\
\hline Faecal streptococcus & 0.231 & 0.112 & 0.523 & -0.005 & 0.042 & 0.210 & -0.078 & -0.142 & 0.081 & -0.030 & 0.582 & 0.431 & 0.184 & -0.119 & -0.095 \\
\hline
\end{tabular}


Table 5. Performance indexes for MLR and PCR in the fitting of the Chlorella vulgaris and Vibrio fischeri toxic responses.

\begin{tabular}{|c|c|c|c|c|c|c|c|c|}
\hline & \multicolumn{4}{|c|}{ MLR } & \multicolumn{4}{|c|}{ PCR } \\
\hline & MAE & RMSE & $d_{2}$ & $\mathrm{R}^{2}$ & MAE & RMSE & $d_{2}$ & $\mathrm{R}^{2}$ \\
\hline Chlorella vulgaris & 1.532 & 1.945 & 0.884 & 0.643 & 1.901 & 2.364 & 0.797 & 0.473 \\
\hline Vibrio fischeri (15 min) & 0.613 & 0.860 & 0.911 & 0.711 & 0.817 & 1.008 & 0.864 & 0.603 \\
\hline
\end{tabular}

parameters. PC2, PC4, PC5, PC6, PC7 and PC8 had important contributions from $\mathrm{Mn}, \mathrm{Zn}$, turbidity, As, Fe and colour, respectively. PC9 to PC15 did not present any significant contribution of the original variables; however, they were used in PCR to analyse if these minor contributions are statistically significant in the ecotoxicological response of living organisms. The regression models using PCs as input variables (PCR) were the following:

$$
\begin{aligned}
\text { C.vulgaris }= & 2.719+0.683(\mathrm{PC} 3)-1.899(\mathrm{PC} 6) \\
& -1.677(\mathrm{PC} 8)+2.841(\mathrm{PC} 9) \\
\text { V.fischeri }= & 1.849-0.442(\mathrm{PC} 4)-1.304(\mathrm{PC} 8) \\
& +1.087(\mathrm{PC} 9)+8.596(\mathrm{PC} 15)
\end{aligned}
$$

Table 4 presents the matrix that multiplied by the original variables matrix gives the values of PCs. These values show how a PC was influenced by each original variable. For instance, negative values showed that the original value and the PC are negatively correlated. Taking values in Table 4 corresponding to high factor loadings (in Table 3) and the regression coefficients for each PC, it is possible to infer the relationship between the original variables and the output variable. If both values have the same signal, the influence is positive; otherwise, the influence is negative. According to this transformation and the regression coefficients given by the models, PCR showed that: (i) C. vulgaris toxic response was negatively influenced by colour and DOC, and positively by $\mathrm{As}, \mathrm{Hg}$ and all bacteriological parameters, especially faecal coliforms; and (ii) $V$. fischeri toxic response was negatively correlated with colour and DOC, and positively with $\mathrm{Zn}$ and faecal coliforms.

Figures 2 and 3 present the comparison between toxicity experimental and calculated values $\left(\mathrm{TU}_{50}\right)$ from MLR and $\mathrm{PCR}$, respectively. Table 5 shows the performance indexes for MLR and PCR. MLR is the regression model that best fit the $C$. vulgaris and $V$. fischeri toxic response with respect to the Leça river water characterization.

\section{Discussion}

\subsection{Multiple linear regression}

The MLR results for $C$. vulgaris showed a negative correlation between the toxic response and the DOC, $\mathrm{Zn}$ and Mn parameters. DOC is extremely important in the transport of metals in aquatic systems, forming strong complexes with metals, enhancing metal solubility while also reducing metal bioavailability. Studies using multispecies laboratory bioassays proved $C$. vulgaris resistance to toxicants like Zn.[43,44].

Turbidity is considered an important variable relative to transport and bioavailability of contaminants in natural waters.[45] In addition, turbidity aff ects the results of tests based on photometric measurements, produces light losses and leads to toxicity overestimation.[46] In the present study, turbidity was positively related to $C$. vulgaris toxic response results due to the scattering of incident light by colloidal and particulate matter in water.

The $V$. fischeri toxic response, according to MLR, presented a negative relation with conductivity and turbidity. Conductivity is related to ionic concentrations and $\mathrm{pH}$. The Microtox ${ }^{\circledR}$ test procedure, based on the inhibition of $V$. fischeri marine bacteria, involves the addition of sodium chloride, therefore, possibly changing sample ionic concentration and, consequently, metals toxic potential. This eff ect may be due to competition between toxic ions and chloride ions in the cellular membrane.[47] Some studies showed silver toxicity diminishing with the raise of salinity up to $25 \%$; however, for salinity above $25 \%$ o an increase in the metal toxicity was observed, which was attributed to osmotic imbalance caused by chloride ions.[48-50]

The hardness, the metals $\mathrm{Fe}, \mathrm{Hg}$ and As and the faecal coliforms presented a positive correlation with the toxic response of $V$. fischeri. Concerning the eff ect of hardness on metals toxicity, it is known that the presence of calcium and magnesium carbonates in water can cause the precipitation of metals, making them insoluble and therefore not available to penetrate into the membranes of living organisms. This eff ect was observed for manganese chronic toxicity in aquatic species Salmo trutta, and also for other metals, such as copper, zinc and cadmium.[51-53] The hardness values obtained for Leça river were normal for surface water and, therefore, the metals $\mathrm{Fe}, \mathrm{Hg}$ and As contributed to global toxic eff ect. Nevertheless, Microtox ${ }^{\circledR}$ test is especially sensitive to several metals, such as $\mathrm{Hg}, \mathrm{Pb}, \mathrm{Zn}$ and $\mathrm{Cu}[54,55]$; the toxicity of heavy metals is highly influenced by matrix eff ects, conditions and concentration, $[56,57]$ The faecal coliforms in Leça river presented extremely high concentrations showing positive correlation with the V.fischeri toxic response probably due to competition between the bacteria, both Gram-negative, heterotrophic and facultative anaerobes. This competition might be for oxygen, 
which would influence the luminescence produced once its mechanism is intrinsically connected to the respiratory metabolism.[58]

\subsection{Principal component regression}

The PCR results for $C$. vulgaris toxic response showed a negative correlation with colour and DOC parameters. In the specific case of surface water samples in the natural environment, the colour is related to high concentrations of DOC, which could explain the inclusion in the same PC (PC8). As algae absorb light energy for photosynthesis, in coloured samples the light provided during the toxicity bioassay may be partially absorbed by the coloured compounds of the surface waters.[59]

Arsenic, mercury and all bacteriological parameters (especially faecal coliforms) showed a positive correlation with $C$. vulgaris toxic response. Algae are generally hyperaccumulators of heavy metals.[1,60-63] However, some studies showed that arsenic is toxic to algae but highly variable data have been reported due to diff erent experimental conditions (e.g. 'no eff ect' concentrations ranged from 0.16 to $1000 \mathrm{mg} / \mathrm{L}$ ).[57] With regard to the bacteriological parameters, a positive correlation was found. It might be related to the fact that bacteria respiration releases carbon dioxide, essential for algae photosynthesis.

According to PCR, the V. fischeri toxic response presented a negative correlation with colour and DOC. A coloured sample may potentially absorb a portion of the light produced by the $V$. fischeri before it reaches the photomultiplier, and the sample may appear more toxic than it really is.[64] In this manner, colour should present a positive and not a negative correlation. The DOC biodegradable fraction consists of organic molecules that can be used by heterotrophic bacteria, such as V.fischeri, as a source of energy and carbon, thus contributing to bacterial metabolism. $\mathrm{Zn}$ and faecal coliforms presented positive correlation with $V$. fischeri toxic response, which agrees with the result obtained by MLR, confirming the idea of competition between $V$. fischeri and coliforms.

\section{Conclusions}

To better understand the interaction of physical, chemical and bacteriological factors involved in a multidimensional process such as the ecotoxicological response, MLR and PCR were applied to the results of $C$. vulgaris and $V$. fischeri toxic response to the Leça river water characterization, both physicochemical and microbiological. According to the results obtained, the first seems to be more sensitive, which is in accordance with most studies presented in literature.

In a general way, and supported by the performance indexes, the MLR seems to be the most appropriate model to the Leça river data, presenting: (i) a negative correlation with DOC, $\mathrm{Zn}$ and $\mathrm{Mn}$, and a positive one with turbidity and As for C. vulgaris toxic response and (ii) a negative correlation with conductivity and turbidity, and a positive one with phosphorus, hardness, $\mathrm{Fe}, \mathrm{Hg}$, As and faecal coliforms for $V$. fischeri toxic response.

The results obtained may be useful in the future to evaluate the eff ect of pollution abatement measures over the water quality of Leça River. This approach will be helpful for the strategy dictated by the water framework Directive 2000/60/EC, which include the classification of water bodies to allow the definition of environmental objectives and the implementation of management programs.

\section{Funding}

J.C.M. Pires thanks the Foundation for Science and Technology, POPH-QREN and FSE for the Post-Doctoral fellowship [SFRH/BPD/66721/2009].

\section{References}

[1] Olguin HF, Puig A, Loez CR, Salibian A, Topalian ML, Castane PM, Rovedatti MG. An integration of water physicochemistry, algal bioassays, phytoplankton, and zooplankton for ecotoxicological assessment in a highly polluted lowland river. Water Air Soil Poll. 2004;155:355-381.

[2] Picado A, Mendonca E, Silva L, Paixao SM, Brito F, Cunha MA, Leitao S, Moura I, Hernan R. Ecotoxicological assessment of industrial wastewaters in Trancao River Basin (Portugal). Environ Toxicol. 2008;23:466-472.

[3] Athey LA, Thomas JM, Skalski JR. Role of acute toxicity bioassays in the remedial action process at hazardous waste sites. Office Water USEPA; EPA/600/8-87/044; 1987.

[4] Ferrari L, de la Torre FR, Demichelis SO, Garcia ME Salibian A. Ecotoxicological assessment for receiving waters with the premetamorphic tadpoles acute assay. Chemosphere. 2005;59:567-575.

[5] Zeliger HI. Toxic eff ects of chemical mixtures. Arch Environ Health. 2003;58:23-29.

[6] Wei DB, Kisuno A, Kameya T, Urano K. A new method for evaluating biological safety of environmental water with algae, daphnia and fish toxicity ranks. Sci Total Environ. 2006;371:383-390.

[7] Meharg AA. Industrial-accidents involving release of chemicals into the environment-ecotoxicology. Environ Technol. 1994;15:1041-1050.

[8] Saddoud A, Abdelkafi S, Sayadi S. Effects of domestic wastewater toxicity on anaerobic membrane-bioreactor (MBR) performances. Environ Technol. 2009;30:13611369.

[9] Gurung A, Hassan SHA, Oh SE. Assessing acute toxicity of effluent from a textile industry and nearby river waters using sulfur-oxidizing bacteria in continuous mode. Environ Technol. 2011;32:1597-1604.

[10] Van Straalen NM, Denneman CAJ. Ecotoxicological evaluation of soil quality criteria. Ecotox Environ Safe. 1989;18:241-251.

[11] USEPA. Permit writer's guide to water quality-based permitting for toxic pollutants EPA 440/4-87-005. Washington, DC: US Environmental Protection Agency; 1987.

[12] USEPA. Technical support document for water qualitybased control EPA-505/2-90-001. Washington, DC: US Environmental Protection Agency; 1991. 
[13] Dizer H, Wittekindt E, Fischer B, Hansen PD. The cytotoxic and genotoxic potential of surface water and wastewater effluents as determined by bioluminescence, UMU-assays and selected biomarkers. Chemosphere. 2002;46:225-233.

[14] USEPA. Methods for measuring the acute toxicity of effluents and receiving waters to freshwater and marine organisms (Fifth Edition) EPA-821-R-02-012. Washington, DC: US Environmental Protection Agency; 2002.

[15] Hakanson L, Malmaeus JM, Bodemer U, Gerhardt V. Coefficients of variation for chlorophyll, green algae, diatoms, cryptophytes and blue-greens in rivers as a basis for predictive modelling and aquatic management. Ecol Model. 2003;169:179-196.

[16] Çamdevýren H, Demyr N, Kanik A, Keskyn S. Use of principal component scores in multiple linear regression models for prediction of chlorophyll-a in reservoirs. Ecol Model. 2005; 181:581-589.

[17] Cacho OJ. Systems modelling and bioeconomic modelling in aquaculture. Aquacult Econ Manage. 1997;1:45-64.

[18] Tuff ord DL, McKellar HN. Spatial and temporal hydrodynamic and water quality modeling analysis of a large reservoir on the South Carolina (USA) coastal plain. Ecol Model. 1999;114:137-173.

[19] Singh KP, Malik A, Sinha S. Water quality assessment and apportionment of pollution sources of Gomti river (India) using multivariate statistical techniques - a case study. Anal Chim Acta. 2005;538:355-374.

[20] Cho KH, Kang JH, Ki SJ, Park Y, Cha SM, Kim JH. Determination of the optimal parameters in regression models for the prediction of chlorophyll-a: a case study of the Yeongsan Reservoir, Korea. Sci Total Environ. 2009;407:2536-2545.

[21] Li SY, Gu S, Tan X, Zhang QF. Water quality in the upper Han River basin, China: the impacts of land use/land cover in riparian buff er zone. J Hazard Mater. 2009;165:17-324.

[22] Su SL, Li D, Zhang Q, Xiao R, Huang F, Wu JP. Temporal trend and source apportionment of water pollution in diff erent functional zones of Qiantang River, China. Water Res. 2011;45:1781-1795.

[23] Kang JH, Lee SW, Cho KH, Ki SJ, Cha SM, Kim JH. Linking land-use type and stream water quality using spatial data of fecal indicator bacteria and heavy metals in the Yeongsan river basin. Water Res. 2010;44:4143-4157.

[24] Lewis MA. Use of freshwater plants for phytotoxicity testing: a review. Environ Pollut. 1995;87(3):319-336.

[25] Pelczar M, Chan E, Krieg N. Microbiology: concepts and applications. 1st ed. New York: McGraw-Hill; 1993. p. 288.

[26] Ruby EG, McFall-Ngai MJ. Oxygen-utilizing reactions and symbiotic colonization of the squid light organ by Vibrio fischeri. Trends Microbiol. 1999;7(10):414-420.

[27] Munkittrick KR, Power EA, Sergy GA. The relative sensitivity of microtox, daphnid, rainbow trout, and fathead minnow acute lethality tests. Environ Toxic Water. 1991;6(1):35-62.

[28] Eaton AD, Clesceri LS, Rice EW, Greenberg AB. Standard methods for the examination of water and wastewater. Washington, DC: American Public Health Association; 2005.

[29] USEPA. Methods for chemical analysis of water and wastes - method 110.2, EPA/600/4-79-020. Washington, DC: US Environmental Protection Agency; 1983.

[30] ISO 9308-01. Water quality - detection and enumeration of Escherichia coli and coliform bacteria - Part 1: membrane filtration method. Geneva, Switzerland: International Organization for Standardization; 2000.

[31] ISO 7899-2. Water quality - detection and enumeration of intestinal enterococci - Part 2: membrane filtration method. Geneva, Switzerland: International Organization for Standardization; 2000
[32] ISO 11348-1. Water quality-determination of the nhibitory eff ect of water samples on the light emission of Vibrio fischeri (luminescent bacteria test). Geneva, Switzerland: International Organization for Standardization; 1998.

[33] Carvalho F, Guilhermino L, Ribeiro R, Goncalves F, Soares AMVM. Metier (modular ecotoxicity tests incorporating ecological relevance) .2. Ecotoxicity of poorly water-soluble compounds - concentration versus dose. Arch Environ Con Tox. 1995;29:431-434.

[34] WDNR. State of wisconsin aquatic life toxicity testing methods manual. Washington, DC: WDNR;2004.

[35] Mutihac L, Mutihac R. Mining in chemometrics. Anal Chim Acta. 2008;612:1-18.

[36] Pires JCM, Martins FG, Sousa SIV, Alvim-Ferraz MCM, Pereira MC. Selection and validation of parameters in multiple linear and principal component regressions. Environ Modell Softw. 2008;23:50-55.

[37] Archives of Environmental Health Ecotoxicology and Environmental Safety, Agirre-Basurko E, Ibarra-Berastegi G, Madariaga I. Regression and multilayer perceptron-based models to forecast hourly $\mathrm{O}_{3}$ and $\mathrm{NO}_{2}$ levels in the Bilbao area. Environ Modell Softw. 2006;21:430-446.

[38] Harman HH. Modern factor analysis. 3rd ed. Chicago: University of Chicago Press; 1976.

[39] Hayter AJ, Wynn HP, Liu W. Slope modified confidence bands for a simple linear regression model. Stat Method. 2006;3:186-192.

[40] Sousa SIV, Pires JCM, Martins FG, Pereira MC, AlvimFerraz MCM. Potentialities of quantile regression to predict ozone concentrations. Environmetrics. 2009;20: 147-158.

[41] Harmel RD, Smith PK. Consideration of measurement uncertainty in the evaluation of goodness-of-fit in hydrologic and water quality modeling. J Hydrol. 2007;337: 326-336.

[42] Gomes AI. Ecotoxicity evaluation in surface waters - application to the water basin of Leça river. Department of Chemical Engineering, Faculdade de Engenharia, Universidade do Porto, (Portuguese) [revised 2007; cited 17th May 2012]. Available from http://repositorio-aberto.up.pt/bitstream/ 10216/12720/2/Texto\%20integral.pdf

[43] Loez CR, Salibián A, Topalián ML. Associations phytoplanctoniques indicatrices de la pollution par zinc. Rev Science Eau. 1998;11:315-332.

[44] Loez CR, Topalián ML, Salibián A. Eff ects of zinc on the structure and growth dynamics of a natural freshwater phytoplankton assemblage reared in the laboratory. Environ Pollut. 1995;88:275-281.

[45] Castane PM, Rovedatti MG, Topalian ML, Salibian A. Spatial and temporal trends of physicochemical parameters in the water of the Reconquista River (Buenos Aires, Argentina). Environ Monit Assess. 2006;117:135-144.

[46] Farre M, Martinez E, Barcelo D. Validation of interlaboratory studies on toxicity in water samples. TRAC Trend Anal Chem. 2007;26:283-292.

[47] Gunkel G. Bioindikation in aquatischen Ökosystemen. Jena, Germany: Gustav Fisher Verlag; 1994.

[48] Ferguson EA, Hogstrand C. Acute silver toxicity to seawateracclimated rainbow trout: influence of salinity on toxicity and silver speciation. Environ Toxicol Chem. 1998;17: 589-593.

[49] Hogstrand C, Wood CM. Toward a better understanding of the bioavailability, physiology and toxicity of silver in fish: implications for water quality criteria. Environ Toxicol Chem. 1998;17:547-561.

[50] Shaw JR, Wood CM, Birge WJ, Hogstrand C. Toxicity of silver to the marine teleost (Oligocottus maculosus): 
eff ects of salinity and ammonia. Environ Toxicol Chem. 1998;17:594-600.

[51] Hart D, Rinker M, Dutton M, Gould R, Snodgrass W, Hogan C. Literature review of environmental toxicity of mercury, cadmium, selenium and antimony in metal mining effluents. Brampton, Ontario: Beak International Incorporated; 2002.

[52] Stubblefield WA, Brinkman SE, Davies PH, Garrison TD. Eff ects of water hardness on the toxicity of manganese to developing brown trout (Salmo trutta). Environ Toxicol Chem. 1997;16:2082-2089.

[53] Williams KA, Green DWJ, Pascoe D. Studies on the acute toxicity of pollutants to freshwater macroinvertebrates. Arch Hydrobiol. 1985;102:461-471.

[54] Bogaerts P, Bohatier J, Bonnemoy F. Use of the ciliated protozoan Tetrahymena pyriformis for the assessment of toxicity and quantitative structure-activity relationships of xenobiotics: comparison with the Microtox test. Ecotox Environ Safe. 2001;49:293-301.

[55] Hsieh CY, Tsai MH, Ryan DK, Pancorbo OC. Toxicity of the 13 priority pollutant metals to Vibrio fisheri in the Microtox (R) chronic toxicity test. Sci Total Environ. 2004;320:37-50.

[56] Farre M, Martinez E, Hernando MD, Fernandez-Alba A, Fritz J, Unruh E, Mihail O, Sakkas V, Morbey A, Albanis T, Brito F, Hansen PD, Barcelo D. European ring exercise on water toxicity using diff erent bioluminescence inhibition tests based on Vibrio fischeri, in support to the implementation of the water framework directive. Talanta. 2006;69:323-333.
[57] Tisler T, Zagorc-Koncan J. Acute and chronic toxicity of arsenic to some aquatic organisms. B. Environ Contam Tox. 2002;69:421-429.

[58] Rodrigues MT. Lumistox application in the determination of sediment samples toxicity. Braga, Portuguese: Minho University; 2005.

[59] Reginatto V. Evaluation of toxicity bioassay with algae Scenedesmus subspicatus for the study of industrial effluents. Campinas: Universidade Estadual de Campinas; 1998. p. 138.

[60] Reddy GN, Prasad MNV. Characterization of cadmium binding-protein from Scenedesmus-quadricauda and Cd toxicity reversal by phytochelatin constituting amino-acids and citrate. J Plant Physiol. 1992;140:156-162.

[61] Lau PS, Lee HY, Tsang CCK, Tam NFY, Wong YS. Eff ect of metal interference, $\mathrm{pH}$ and temperature on $\mathrm{Cu}$ and $\mathrm{Ni}$ biosorption by Chlorella vulgaris and Chlorella miniata. Environ Technol. 1999;20:953-961.

[62] Toumi A, Belkoura M, Benabdallah S, El Alami M, Idrissi LL, Nejmeddine A. Eff ect and bioaccumulation of heavy metals ( $\mathrm{Zn}, \mathrm{Cd})$ on Micractinium pusillum alga. Environ Technol. 2007;28:19-23.

[63] Aksu Z, Kutsal T. A comparative-study for biosorption characteristics of heavy-metal ions with $C$-vulgaris. Environ Technol. 1990;11:979-987.

[64] Microbics Corporation. A microtox manual - how to reduce microtox test data. Carlsbad, CA: Microbics Corporation; 1988. 